\title{
Mutagenicity of Materials related with Cosmetics
}

\author{
Kazuyoshi Morita, Mitsuko Ishigaki and Takashi Abe
}

\begin{abstract}
We reexamined safety of some cosmetic materials on a hereditary toxicity.
The cosmetic materials tested were preservatives, Sunscreens, antioxidants, hormones and surfactants.

Mutagenicity assay were carried out for Rec-assay using Wild and Recombination-deficient strains of B.Subutilis and Reversion assay using Salmonella typhimurium TA98 and TA100 with or without the microsomal activation $( \pm S-9 \mathrm{mix})$. In addition to the above-described procedures, Rec-assay with irradiating fluorescent lump or cold incubation were carried out to some materials, such as sunscreens and antioxidants.

Irg-DP300, a preservative, was weak rec-positive at very high concentration such as $5 \mathrm{mg} /$ disk, but negative on revession assay.

Both 8-MOP and O-201 newly found out as positive control of photo-rec assay were clearly rec-positive by irradiation of fluorescent lump, but all of sunscreens and antioxidants were negative.

Estradiol, a hormone, induced slightly more revertants than control with $\mathrm{S}-9_{\mathrm{mix}}$ and three anion surfactants of sulfate derivatives (Surf-1,2,4) and two nonion surfactants of cetyl ether and lanolin alcohol derivatives (Surf-13,14) also exhibited the same effects with or without S-9 $9_{\mathrm{mix}}$, but we couldn't sufficiently recognize these mutagenicity. These phenomena are yet obscure whether due to any reasons.
\end{abstract}

\section{1. 緒 言}

化粧品に関係した安全性試験としては，大別すると， 局所毒性と全身毒性に分けられる。この内，化粧品は皮 膚と接触するものであることから，従来より，皮膚刺激 性, 眼粘膜刺激性, アレルギー性試験等の局所毒性試験 が第一義的なるのとなっている。しかしながら，化粧品 の長期連用による全身への影響も看過でさない。そのた め, 化粧品原料の急性, 亜急性, 慢性等の一般毒性試験 も広く研究されている。

最近, 更に発癌性との関連から突然变異原性に関心が もたれて来ている。小動物を利用した発癌性試験は, コ スト, 時間, 労力, 設備等の点で限度があり, 実際応用

鐘紡(侏)化粧品研究所: $\mathbf{T} 250$ 神奈川県小田原市寿町 5 丁目 3 番 28 号

Cosmetics Laboratory, Kanebo Ltd., 3-28, Kotobuki-5-chome, Odawara-shi, Kanagawa-ken, 250 .
面に拈いて，困難があるため，短期予測試験として突然 変異性試験が広く利用されている。

突然变異原性と発癌性との間の因果関係は必ずしも, 明確ではないが, 既知の発癌物質の大部分に, 突然変異 原性が確認されて和り, 一方突然変異原物質として見つ かった $\mathrm{AF}-2^{1 \sim 4)}$ やリプトファンの加熱分解物 Trpp-1 や Trp-p-2 等 ${ }^{5 \sim 7}$ が最終的には, 小動物により癌原 性が確かめられている。そして, 多くの突然変異原物質 は, 発癌プロセスに护る Initiation の役割を果たして いるのではないかと考光られている。

そこで, 細菌系による突然変異原性試験を用いて, 化 粧品関連物質の変異原性を検討することは, 化粧品関連 物質の安全性の一環として意義があると考えられる。

既に, 化粧品原料の突然変異原性については, いくつ か検討がなされて特り，酸化染料 10,11 色素 ${ }^{12,13)}$ 酸化防止 剂 ${ }^{14)}$ 界面活性剂 ${ }^{15,16)}$ 並びに防腐剂 ${ }^{17)}$ 等の一部が取り上げ られている。

今回, 我々は, 前記の既に検討されている物質を含 
め, 更に未検討の化粧品関連物質 (一部, 本研究では比 較物質として癌原物質や起炎物質を置く)を我統的に取 り上げ，賀田8)等が開発した DNA 損傷性を調べる DNA 修復試験と, Ames 等" が開発した細菌の栄養要求性を 指標とした復帰变異試験によって突然变異原性を検討し た。取り上げた物質は防腐剤, 紫外線吸収剤, 酸化阪止 剤, ホルモン並びに各種界面活性剂等である。

\section{2. 実 験}

\section{2-1 被検試料並びに対照試料}

\section{2-1-1 被検試料}

被検試料は, Table-1 に示した様に防腐剤 9 種, 紫外 線吸収剂 6 種, 酸化防止剂 8 種, ホルモン 7 種, 並びに界面活性郕として，アニオン系 5 種, カチオン采

Table-1. Test materials. Common Name \& Chemical Name.

\begin{tabular}{|c|c|c|c|c|}
\hline \multicolumn{2}{|c|}{ Preservatives } & & Antioxidants & \\
\hline Pre & -1 & Methyl-p-hydroxybenzoate & Anti - 1 & 3,5-di-tert-butylhydroxy toluene (BHT) \\
\hline Pre & -2 & Ethy1-p-hydroxybenzoate & Anti - 2 & Butylhydroxy anisol (BHA) \\
\hline Pre & -3 & Propy 1-P-hydroxybenzoate & Anti -3 & Normal-propylgallate * \\
\hline pre & -4 & Buty1-P-hydroxybenzoate & Anti -4 & Guaiaconic acid $\mathrm{C}_{22} \mathrm{H}_{26}{ }^{\circ} \&$ \\
\hline Pre & -5 & Sodium dehydroacetate & & Guaiaretic acic $\mathrm{C}_{20} \mathrm{H}_{24}{ }_{4}^{\circ}$ (Resine Guaiac) \\
\hline Pre & -6 & Sorbic acid & & Isoamyl gallate * \\
\hline Pre & -7 & $\begin{array}{l}\text { 3-trifluoro-methyl-4,4-dichloro } \\
\text { carbanilide (Irgasan-CF3) }\end{array}$ & $\begin{array}{l}\text { Anti }-5 \\
\text { Anti }-6\end{array}$ & $\begin{array}{l}\text { Isoamyl gallate * } \\
\text { Nordihydroguaiaretic acid * }\end{array}$ \\
\hline Pre & -8 & $\begin{array}{l}\text { 2,4,4-trichloro-2-hydroxy-diphenyl } \\
\text { ether (Irgasan-DP300) }\end{array}$ & $\begin{array}{l}\text { Anti }-7 \\
\text { Anti }-8\end{array}$ & $\begin{array}{l}\text { Ascorbyl-di-palmitate. } \\
\text { Tocopherol (Vitamin E) }\end{array}$ \\
\hline Pre & -9 & Sodium benzoate & Hormones & \\
\hline \multicolumn{2}{|l|}{ Sunscreens } & & Horm - I & $3,17 \beta$-dihydroxy $-\Delta^{1,3,5,(10)}$-estra- \\
\hline Sun & -1 & Anyl-p-dimethylamino benzoate \& & & triene ( $\beta$-Estradiol) \\
\hline Sun & -2 & $\begin{array}{l}\text { Amyl-P-methylamino benzoate (Escarol 506) } \\
\text { 2-ethyl-hexyl-p-dimethylamino }\end{array}$ & Horm - 2 & $\begin{array}{l}17 x \text {-ethyny } 1-\Delta^{1}, 3,5,(10) \text { estratriene- } \\
3,17 \beta \text {-diol (Etynyl-estradiol) }\end{array}$ \\
\hline sun & -3 & $\begin{array}{l}\text { benzoate (Escarol } 507 \text { ) } \\
\text { 2-hydroxy-4-methoxy-benzophenon }\end{array}$ & Horm - 3 & $\begin{array}{l}\text { 1,4-pregnandiene-3,20-dione-118,17 } \\
\text { 21-triol (Predonizolone) }\end{array}$ \\
\hline Sun & -4 & $2,2,4,4$-tetrahydroxy-benzophenon & Horm - 4 & 3 -hydroxy-17-keto- $\Delta^{1,3,5(10)}$-estr- \\
\hline Sun & -5 & $\begin{array}{l}\text { Isopropy 1-4-methoxy cinnamate (main) } \\
\text { Methyl-2,5-diisopropyl cinnamate } \\
\text { (5-108) (Neoheriopan) }\end{array}$ & Horm -5 & $\begin{array}{l}\text { atriene (Estrone) } * * \\
\Delta^{4} \text {-androsterone-17 -propionate-3- } \\
\text { one (Teststeronepropionate) } \star *\end{array}$ \\
\hline Sun & -6 & 4-imidazoleacrylic acid ethyl ester & Horm -6 & $\begin{array}{l}\Delta^{4} \text {-pregnen-17,21-diol-3,11,20-tr- } \\
\text { ione (Cortisone) } \star \star \star\end{array}$ \\
\hline & & & Hoxm - 7 & $\begin{array}{l}4,4 \text {-dihydroxy- } \alpha, \beta-\text { trans-diethylstil- } \\
\text { bestrol (Diethylstilbestrol) }\end{array}$ \\
\hline
\end{tabular}

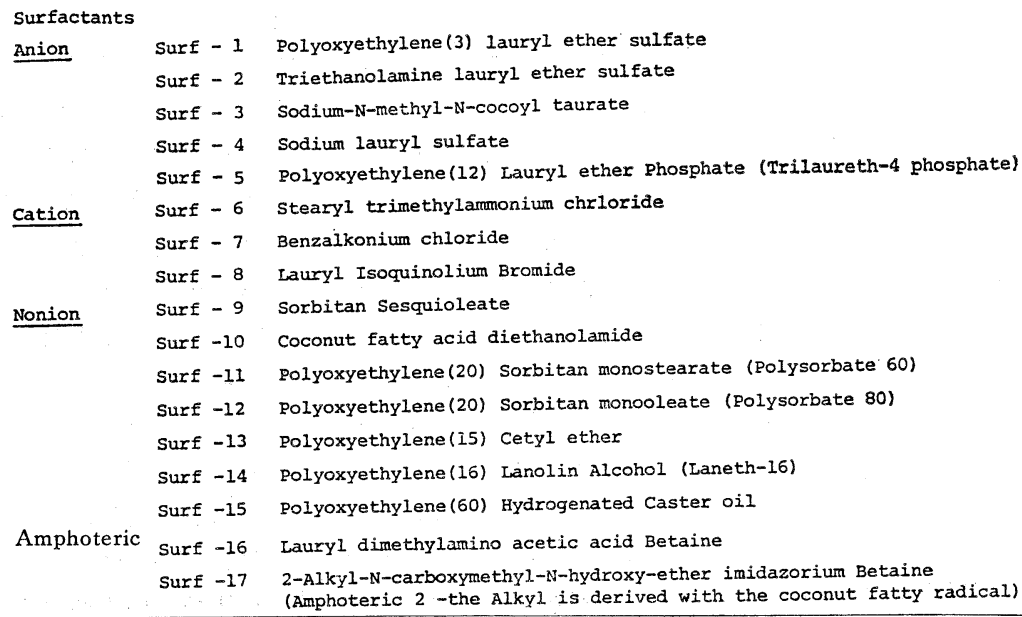


化粧品関連物質の突然変異原性

Table-2. Positive control

\begin{tabular}{cll} 
Abbreviation & \multicolumn{1}{c}{ Chemical Name } & Source \\
\hline M-C & Mitomycin C & wako Chem. Co. \\
O-201 & 4,5-dibromofluorescein & Thomasset colors. \\
$8-$ MOP & 8-methoxy psoralen & Shigma Chem. \\
$2-\mathrm{NF}$ & 2-nitrofluorene & wako Chem. Co. \\
$\mathrm{AF-2}$ & $2-(2$-fury1)-3-(5-nitro- & N.I:G. \\
& 2-furyl)acrylamide & \\
2AA & 2-amino anthracene & wako Chem. Co. \\
\hline
\end{tabular}

3 種, ノニオン系 7 種, 両性界面活性剂 2 種の計 17 種を 取り上げ検討した。和光純薬侏, 東京化成侏, シグマケ ミカル購入試料は, 試薬特級又は試薬純度品であり, そ の他の全ての原料は, 粧原基グレードの市販品である。

2-1-2 対照試料

対照試料は, Table-2 に示した。各種 Rec-assay の 此較対照品として用いた4, 5-ジブロムフルオレッセン （O-201）は，トマセット製を使用し，8-メトキシプソ ラーレン (8-MOP) は, シグマケミカルより購入し，マ イトマイシンーC (M-C) は, 和光純薬侏上り購入した。 また, 2-(2-フリル)-3-(5-ニトロ-2-フリル) アクリル アミド (AF-2)は, 国立遺伝研変異遺伝部より分与を受 けた。復帰変異試験の比較対照品として用いた2-アミ,

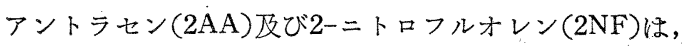
和光純薬侏上り購入した。

2-1-3 S-9 誘導物質

S-9 誘導物質として使用した PCB (ジクロルビフェ ニル, approx $\left.\mathrm{C}_{12} \mathrm{H}_{8} \mathrm{Cl}_{2}=23310\right)$ は, 和光純薬(侏)より 購入した。PCBをコーンオイルに溶解して用いた。

\section{2-2 指標菌株}

各種 Rec-assay そは， DNA 損傷を細胞酥素によ って組換修復可能な変異株 Bacillus Subtilis H 17 $\left(\mathrm{Rec}^{+}\right)$と組換修復能を欠損した変異株M-45 $\left(\mathrm{Rec}^{-}\right)$ の 2 株を供試した。また，復帰変異試験（Reversion一 assay) には Salmonella typhimurium TA 98 (フレー ムシフト変異型) と TA 100 (塩基交換変異型)を供試し た。尚, これらの指標菌株は, 国立遺伝研变異遺伝部よ り分与を受けた。

\section{2-3 指標菌株の前培養}

Rec-assay 用飞使用する Bacillus Subtilis H 17 ま たはM 45 の菌株を，1.0\%牛肉エキス（極東製薬(侏製） $1.0 \%$ ポリペプトン (大五栄養化学(侏製), $0.5 \%$ 食塩の 組成からなるB-2 broth に殖菌し, $37^{\circ} \mathrm{C}, 1$ 晚振湯培養 した。その菌增殖した培養液に最終濃度 $12.5 \%$ になる 様にグリセリンを加党，使用まで, $-80^{\circ} \mathrm{C}$ 飞保存した。
復㷌変異試験飞使用する Salmonella typhimurium TA 98 または TA 100 のそれぞれの菌株を, あらかじめ 最終濃度 $33 \mu \mathrm{g} / \mathrm{ml}$ のアンピシリンナトリウム (三共㮫製) を加えてある前記 B-2 broth 飞殖菌後, $37^{\circ} \mathrm{C}, 1$ 晚静 置培養した。气の增殖した菌液を $3500 \mathrm{rpm}, 10$ 分遠心集 菌した。集菌後, $1 / 15 \mathrm{M}$ リン酸緩衝液で 2 度洗浄をくり 返し,再度集菌した。その菌をMM broth $\left(0.1 \%\left(\mathrm{NH}_{4}\right)_{2}\right.$ $\mathrm{SO}_{4}, \quad 1 \% \mathrm{KH}_{2} \mathrm{PO}_{4}, 0.01 \% \mathrm{MgSO}_{4} \cdot 7 \mathrm{H}_{2} \mathrm{O}, 0.05 \%$ ク エン酸ナトリウムの組成で, $\mathrm{KOH} て ゙ \mathrm{pH} 7.0$ 亿調製した 塩培地）に再懸濁した。この菌液に最終濃度 $12.5 \%$ に なる様にグリセリンを加えて, 使用までー $80^{\circ} \mathrm{C}$ に保存 した。

\section{2-4 試験用培地}

Rec-assay 用培地としては, 以下の B-2 寒天培地(前 記B-2 broth 飞寒天末 $15 \mathrm{~g}$ を加光, pH7.0亿調製後, 高 圧蒸気滅菌して作成した）を使用した。

復帰変異試験用培地としては, Vogel Bonner E 培地 を改変した Salt Mixture を含む, 以下の組成の MBB 培地を用いた。

MBB 寒天培地 : $40 \%$ グルコース $10 \mathrm{ml}, \mathrm{MM}$ broth (X20)50ml, Difco Nutrient Broth(0.8\%)10ml, ビオチ ン $(100 \mu \mathrm{g} / \mathrm{ml}) 1 \mathrm{~m} l$, 寒天末(Difco) $15 \mathrm{~g}$, 蒸留水 $930 \mathrm{~m} \ell$ 。 重層用軟寒天は，寒天 (Difco) $0.6 \%$ と食塩 $0.6 \%$ で作 成した。

\section{2-5 突然変異原性試験}

\section{2-5-1 修復試験 (Rec-assay)}

Bacillus Subtilis H 17 と M 45 両株の $-80^{\circ} \mathrm{C}$ 保存株 を融解後, 小型ピペットを用いて B-2寒天培地上飞起点 が接触しないようにストリークした。被検試料は DMSO （ジメチルスルフォキシド）または蒸留水に溶解した。 直径 $8 \mathrm{~mm}$ のディスクに $0.05 \mathrm{~m}$ 浸ませ, ストリークし た菌株の開始点を括扣う様に置き, $37^{\circ} \mathrm{C}$ で一夜培養後, 両株の成長阻止带の長さを測定した。陽性対照として, マイトマイシンCまたは $\mathrm{AF}-2$ を用いた。

2-5-2 Cold-incubation 併用修復試験 (Cold-Rec) 
前記 Rec-assay と同様, Bacillus Subtilis H 17 と M 45 両株を B-2 寒天培地にストリークし, 被検試料を 浸ませたディスクをストリークした菌株の開始点を利お ら様に置いた。この寒天平板を $\mathrm{O}^{\circ} \mathrm{C}$, 一夜静置し, 被検

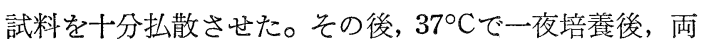
株の成長阻止帯の長さを測定した。

2-5-3 光照射併用修復試験 (Photo-Rec)

前記 Rec-assay と同様, Bacillus Subtilis H 17 と M45 両株を B-2 寒天培地にストリークし, 被検試料を 浸ませたディスクをストリークした菌株の開始点を和括 ら様に置いた。この寒天平板を白色炟光灯 (東芝FLR, $20 \mathrm{~S} \cdot \mathrm{W} / \mathrm{M})$ で $10 \mathrm{~cm}$ の距離で連続照射し, $37^{\circ} \mathrm{C}$, 一 夜培養後, 両株の成長阻止帯の長さを測定した。陽性対 照としては, 我々が各種化学物質の突然変異原性をスク リーニングする中で見いだした 8 MOP (Fig.-1 参照) を用いた。

2-5-4 復帰変異試験 $(-\mathrm{S}-9 \mathrm{mix})$

復帰変異試験には, ヒスチジン要求性株の Salmonella Typhimurium TA 98 (フレームシフト変異型) と TA 100 (塩基交換変異型)，を用いた。 $-80^{\circ} \mathrm{C}$ に保存してあ るT A株を融解後，使用した。

保存菌 $0.1 \mathrm{~m} l$ と被検試料溶液 $0.1 \mathrm{~m} \ell$ を $3 \mathrm{~m} \ell$ 重層用 軟寒天に加光, 予め作成して和いた選択培地の MBB 培
地上に重層し, 均一に拡げ固化した。 $37^{\circ} \mathrm{C} て ゙ 2$ 日間培 養後, 復帰変異コロニー数を計数した。陽性対照とし て，2-ニトロフルオレンを用いた。尚, 試験に用いた菌 液, 被検試料液は雑菌の混入のない事を確認した。

2-5-5 代謝活性化併用による復帰 変 異 試験 (+ S$9 \operatorname{mix}$ )

日本クレア株より購入した S D 系雄ラット (8 weeks, $188 \mathrm{~g}$ ）に $\mathrm{PCB} 500 \mathrm{mg} / \mathrm{kg}$ を 1 回腹腔内に投与し, 投与 4 日後の晚より絶食させ，5 日目に肝臓を摘出した。動 物を断頭屠殺し, 充分放血後, 摘出した肝蔵を, 直ちに 氷冷した $0.15 \mathrm{M} \mathrm{KCl}$ 溶液にて洗浄した。 $2 \mathrm{ml} / \mathrm{g}$ 肝の割 合で $\mathrm{KC1}$ 溶液を加えて, ホモジナイズし, $9000 \times \mathrm{g}$ で 10分間遠心後, その得られた上清を実験に用いた。尚, 全ての操作は $5^{\circ} \mathrm{C}$ 以下で行った。実験に用いた反応液 (S-9 mix) $1 \mathrm{~m} \ell$ 中の組成は, 肝臟ホモジネート上清 $0.3 \mathrm{~m} \ell, \mathrm{MgCl}_{2} 8 \mathrm{mM}, \mathrm{KCl} 33 \mathrm{mM}$, グルュース-6-リ ン酸 $5 \mathrm{mM}, \mathrm{NADP}^{+} 4 \mathrm{mM}$ 並びに $\mathrm{Na}$-リン酸緩衝液 (pH 7.4) $100 \mathrm{mM}$ から成る。

軟寒天液に菌液 $0.1 \mathrm{~m} \ell, \mathrm{S}-9 \mathrm{mix} 0.3 \mathrm{~m} \ell$, 被検試料液 $0.1 \mathrm{~m} \ell$ 加えて良く混合し, 選択培地の $\mathrm{MBB}$ 培地上に 拡げた。 $37^{\circ} \mathrm{C} て ゙ 2$ 日間培養後, 復帰変異コロニー数を 計数した。陽性対照として2-アミノアントラセンを用い た。尚, 試験に用いた菌液, 試料溶液並びに S-9mixは,

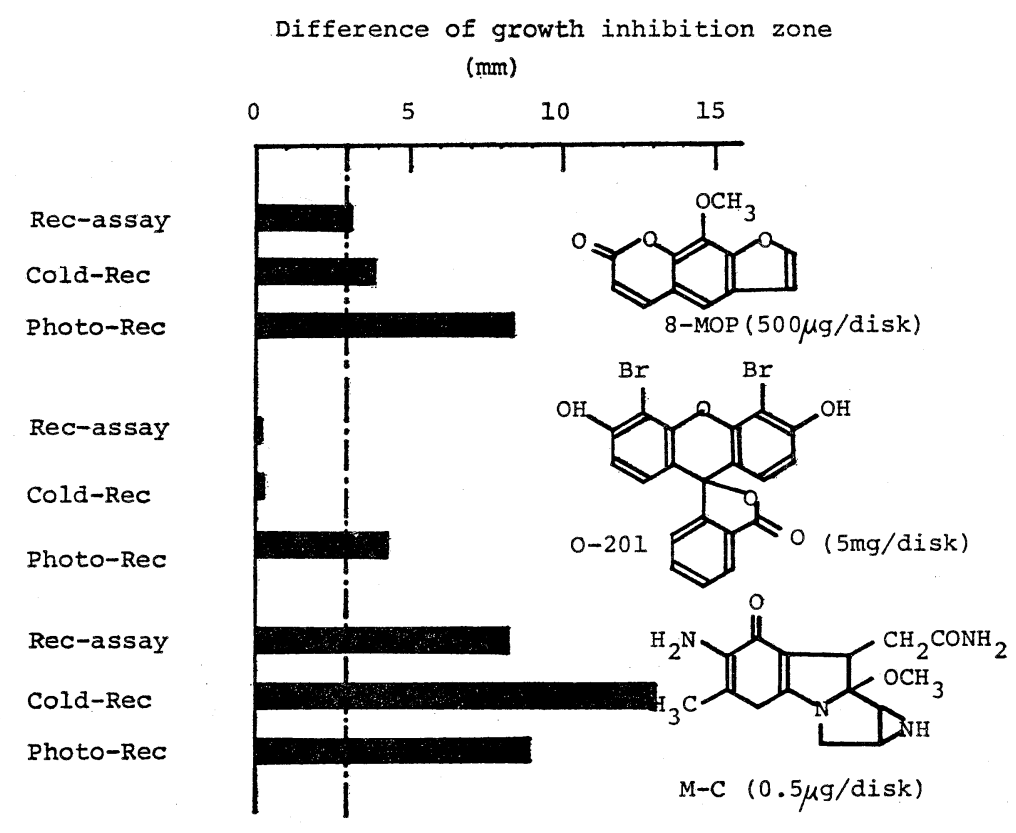

Fig. - 1 Comparison of various Rec-assay. 
雑菌の混入のない事を確認した。

それぞれの被検試料に対して，実施した試験方法を

Table-3 になとめて表わした。防腐剤, ホルモン並びに 界面活性剂は Rec-assay と代謝活性化を含告復帰变異 試験( \pm S-9 mix) により, 紫外線吸収剤並びに酸化防止 剂については, 通常の Rec-assay の他に, Cold-Rec, Photo-Rec，並びに代謝活性化を含も復帰変異試験によ り突然変異原性を検討した。

Table-3. List of assays tested

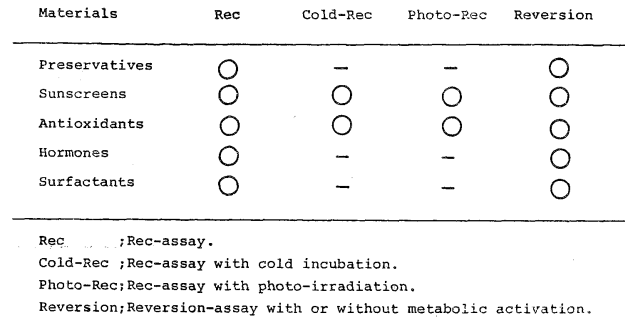

\section{3. 結 果}

今回, 突然変異原性試験を実施するに当り, 我々は, Photo-Rec assay の陽性対照物質について, いくつか 検討を進めて来た。その結果, Fig. -1 に示す様に色素の O-201 では, 光照射をして初めて, 陽性を示し, Photodynamic effect による DNA 損傷性を起こすことを認 めた。 8 MOP では Cold-Rec に打いて明らかな陽性を 示し, 更に, 光照射でより顕著な陽性を示して, その DNA 損傷性を認めた。特にこの $8 \mathrm{MOP}$ が, 顕著な結 果を示したことから, Photo-Rec assay の陽性対照とし て取り上げた。

\section{3-1 防崤剤の突然変異原性}

\section{3-1-1 DNA 修復試験結果}

防腐剤について, DNA 修復試験の結果を Table-4 に 示した。溶媒として用いた DMSO では, H 17, M 45 の 両株に対し, 全く生育阻止帯差を認めない。しかし, 陽 性対照として用いた既知変異原性物 質の AF-2（5 $\mu \mathrm{g}$ disk) 並びにM-C $(0.5 \mu \mathrm{g} / \mathrm{disk}) て ゙ は$, 両株の間に著明 な生育阻止带の差を示し, DNA 損傷性を認めた。それ に対し，試験に供した 9 種の防腐阂中，Irg-DP 300 (Pre-8) を除く，8種の防腐剤では被検濃度内で両株 に対し, 生育阻止帯の差をほとんど示さず, 陰性の結果 であった。一方, Irg-DP 300 では, 高濃度の $5 \mathrm{mg} / \mathrm{disk}$ で, 両株の間に生育阻止帯の差があり, 弱い陽性と考兄
Table-4. Rec-assay of Preservatives.

\begin{tabular}{|c|c|c|c|c|}
\hline \multirow{2}{*}{ Chemical } & \multirow{2}{*}{$\begin{array}{l}\text { concents. } \\
\text { (ng/disk) }\end{array}$} & \multicolumn{2}{|c|}{ B.Subutilis. } & \multirow{2}{*}{$\begin{array}{c}\text { Difference } \\
\text { of } \\
\text { inhibition }\end{array}$} \\
\hline & & $\mathrm{H} 17\left(\mathrm{Rec}^{+}\right)$ & M45 (Rec') & \\
\hline \multirow[t]{3}{*}{ Pre -1} & 5.0 & 2.6 & 2.6 & 0 \\
\hline & 0.5 & 0 & 0 & 0 \\
\hline & 0.05 & 0 & 0 & 0 \\
\hline \multirow[t]{3}{*}{ Pre -2} & 5.0 & 2.4 & 2.9 & 0.5 \\
\hline & 0.5 & 0 & 0 & 0 \\
\hline & 0.05 & 0 & 0 & 0 \\
\hline \multirow[t]{3}{*}{ Pre - 3} & 5.0 & 2.6 & 2.9 & 0.3 \\
\hline & 0.5 & 2.5 & 2.8 & 0.3 \\
\hline & 0.05 & 0 & 0 & 0 \\
\hline \multirow{3}{*}{ Pre -4} & 5.0 & 3.7 & 4.1 & 0.4 \\
\hline & 0.5 & 3.0 & 3.6 & 0.6 \\
\hline & 0.05 & 0 & 0 & 0 \\
\hline \multirow[t]{3}{*}{ Pre - 5} & 5.0 & 0 & 0 & 0 \\
\hline & 0.5 & 0 & 0 - & 0 \\
\hline & 0.05 & 0 & 0 & 0 \\
\hline \multirow[t]{3}{*}{ Pre -6} & 5.0 & 3.2 & 3.2 & 0 \\
\hline & 0.5 & 0.9 & 0.9 & 0 \\
\hline & 0.05 & 0 & 0 & 0 \\
\hline \multirow[t]{3}{*}{ Pre - 7} & 5.0 & 5.3 & 6.6 & 1.3 \\
\hline & 0.5 & 5.8 & 6.8 & 1.0 \\
\hline & 0.05 & 6.3 & 6.4 & 0.1 \\
\hline \multirow[t]{3}{*}{ pre - 8} & 5.0 & 12.3 & 15.7 & $3.4^{\star}$ \\
\hline & 0.5 & 21.5 & 14.2 & 2.7 \\
\hline & 0.05 & 11.8 & 12.8 & 0.6 \\
\hline \multirow[t]{3}{*}{ Pre - 9} & 5.0 & 0 & 0 & 0 \\
\hline & 0.5 & 0 & 0 & 0 \\
\hline & 0.05 & 0 & 0 & 0 \\
\hline DMSO & - & 0 & 0. & 0 \\
\hline$A F-2$ & $5 \mu \mathrm{g} / \mathrm{disk}$ & 8.9 & 27.4 & 8.5 \\
\hline$M-C$ & $0.5 / \mu \mathrm{g} / \mathrm{disk}$ & 4.3 & 13.6 & 9.3 \\
\hline
\end{tabular}

Table-5. Reversion assay of Preservatives with or without $\mathrm{S}-9_{\mathrm{mix}}$.

\begin{tabular}{|c|c|c|c|c|c|}
\hline \multirow{3}{*}{ Chemical } & \multirow{3}{*}{$\begin{array}{c}\text { Concents. } \\
(\mu(g / P)\end{array}$} & \multicolumn{4}{|c|}{ His $^{+}$revertants per plate } \\
\hline & & \multicolumn{2}{|c|}{ TA98 } & \multicolumn{2}{|c|}{ TA100 } \\
\hline & & $-5-9_{\operatorname{mix}}$ & $+5-9_{\operatorname{mix}}$ & $-S-9 \operatorname{mix}$ & $+S-9_{\text {mix }}$ \\
\hline \multirow[t]{3}{*}{ Pre - 1} & 100 & 34 & 33 & 193 & 186 \\
\hline & 10 & 34 & 36 & 184 & 159 \\
\hline & 1 & 42 & 43 & 181 & 164 \\
\hline \multirow[t]{3}{*}{ Pre -2} & 100 & 48 & 30 & 186 & 184 \\
\hline & 10 & 39 & 40 & 192 & 184 \\
\hline & 1 & 49 & 43 & 185 & 172 \\
\hline \multirow[t]{3}{*}{ Pre - 3} & 10 & 39 & 41 & 211 & 180 \\
\hline & 1 & 49 & 41 & .184 & 180 \\
\hline & 0.1 & 38 & 45 & 185 & 182 \\
\hline \multirow{3}{*}{ Pre -4} & 10 & 42 & 44 & 194 & 182 \\
\hline & 1 & 40 & 43 & 192 & 179 \\
\hline & 0.1 & 49 & 34 & 183 & 182 \\
\hline \multirow[t]{3}{*}{ Pre - 5} & 100 & 43 & 40 & 214 & 179 \\
\hline & 10 & 41 & 33 & 184 & 183 \\
\hline & 1 & 38 & 39. & 185 & 184 \\
\hline \multirow[t]{3}{*}{ Pre - 6} & 10 & 45 & 47 & 182 & 175 \\
\hline & 1 & 42 & 39 & 188 & 178 \\
\hline & 0.1 & 39 & 44 & 196 & 178 \\
\hline \multirow{4}{*}{ Pre -7} & 10 & kill & NT & kill & NT \\
\hline & 1 & 24 & kill & 178 & 138 \\
\hline & 0.1 & 33 & 38 & 186 & 176 \\
\hline & 0.01 & 40 & 39 & 190 & 181 \\
\hline \multirow[t]{3}{*}{ Pre -8} & 1 & kill & 22 & kill & 174 \\
\hline & 0.1 & 33 & 35 & 174 & 166 \\
\hline & 0.01 & 37 & 41 & 193 & 177 \\
\hline \multirow[t]{3}{*}{ Pre - 9} & 100 & 45 & 37 & 193 & 189 \\
\hline & 10 & 32 & 43 & 175 & 174 \\
\hline & 1 & 36 & 44 & 191 & 183 \\
\hline DMSO & - & 41 & 40 & 191 & 175 \\
\hline $2-\mathrm{NF}$ & 10 & 3128 & - & 940 & - \\
\hline $2 \mathrm{AA}$ & 5 & - & 2019 & - & 1506 \\
\hline
\end{tabular}

NT : not tested 
られた。しかし，0.5 mg/disk 以下の濃度では，両株の 阻止帯の差は dose に対応して徐々に低下した。

\section{3-1-2 復帰変異試験結果}

防腐剂の復帰変異試験結果は Table-5 に示した。陽

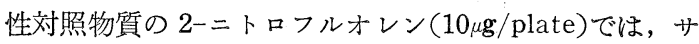
ルモネラ TA 98 および TA 100 の両株に対し, 対照 (DMSO) と比較して著明な復帰変異コロニ一数の増加 があった。また，代謝活性化を必要とする突然変異原性 物質 2 -アミノアントラセン ( $5 \mu \mathrm{g} /$ plate $)$ では, ラット 肝ミクロゾームの代謝酵素系を使用することにより（+ S-9 mix), TA 98 並びに TA100 の両株に対し，著明な 復帰変異コロニ一数の増加を示し, その突然変異原性が 認められた。それに対し，9種の防腐剂については本試 験の濃度範囲内で突然変異原性を調べたが，取り上げた 防腐剤についてはいずれも突然変異原性は見られなかっ た。Rec-assay で弱い陽性を示したIrg-DP300について も，その突然変異原性を認めることができなかった。

\section{3-2 紫外線吸収剂の突然変巽原性}

\section{3-2-1 DNA 修復試験結果}

紫外線吸収剂について DNA 修復試験を検討した結果 を Table-6 に示した。

Table-6. Rec-assay of Sunscreens

\begin{tabular}{|c|c|c|c|c|c|c|c|}
\hline \multirow[t]{2}{*}{ Chemical } & \multirow{2}{*}{$\begin{array}{l}\text { Concents. } \\
\text { (mg/disk) }\end{array}$} & \multicolumn{2}{|c|}{ Rec } & \multicolumn{2}{|c|}{ Cold-Rec } & \multicolumn{2}{|c|}{ Photo-Rec } \\
\hline & & $\mathrm{H} 17 / \mathrm{M} 45 \mathrm{i}$ & inhibit. & $\mathrm{Bl} 7 / \mathrm{M} 45$ & inhibit. & $\mathrm{H} 17 / \mathrm{M} 45$ & \\
\hline \multirow[t]{3}{*}{ Sun - 1} & 5.0 & $2.3 / 2.3$ & 0 & $2.0 / 2.5$ & 0.5 & $2.2 / 2.6$ & 0.4 \\
\hline & 0.5 & $2.5 / 2.6$ & 0.1 & $0.3 / 1.6$ & 1.3 & $0 / 1.2$ & 1.2 \\
\hline & 0.05 & $1.9 / 2.2$ & 0.3 & $2.0 / 2.0$ & 0 & $1.9 / 2.9$ & 1.0 \\
\hline \multirow[t]{3}{*}{$\operatorname{sun}-2$} & 5.0 & $0.3 / 2.9$ & 2.6 & $1.9 / 2.5$ & 0.6 & $0 / 1.6$ & 1.6 \\
\hline & 0.5 & $0.7 / 2.8$ & 2.1 & $0 / 1.3$ & 1.3 & $0 / 0$ & 0 \\
\hline & 0.05 & $1.1 / 2.6$ & 1.5 & $0 / 1.6$ & 1.6 & $0 / 0$ & 0 \\
\hline \multirow{3}{*}{ Sun -3} & 5.0 & $0 / 0$ & 0 & $1.7 / 1.7$ & 0 & $0 / 1.6$ & 1.6 \\
\hline & 0.5 & $0 / 0$ & 0 & $0 / 2.1$ & 2.1 & $0.7 / 2.9$ & 2.2 \\
\hline & 0.05 & $1.8 / 1.8$ & 0 & $0 / 0.6$ & 0.6 & $0 / 0.4$ & 0.4 \\
\hline \multirow[t]{3}{*}{$\operatorname{sun}-4$} & 5.0 & $0 / 0$ & 0 & $0 / 0$ & 0 & $0 / 0$ & 0 \\
\hline & 0.5 & $0 / 0$ & 0 & $0 / 0$ & 0. & $0 / 0$ & 0 \\
\hline & 0.05 & $0 / 0$ & 0 & $0 / 0$ & 0 & $0 / 0$ & 0 \\
\hline \multirow[t]{3}{*}{ Sun -5} & 5.0 & $2.8 / 2.9$ & 0.1 & $2.0 / 3.3$ & 1.3 & $2.1 / 2.7$ & 0.6 \\
\hline & 0.5 & $2.3 / 3.5$ & 1.2 & $1.6 / 2.5$ & 0.9 & $1.5 / 2.2$ & 0.7 \\
\hline & 0.05 & $0 / 0$ & 0 & $0 / 0$ & 0 & $0 / 0$ & 0 \\
\hline \multirow[t]{3}{*}{ Sun -6} & 5.0 & $2.4 / 3.0$ & 0.6 & $1.9 / 3.5$ & 1.6 & $0 / 2.5$ & 2.5 \\
\hline & 0.5 & $0.8 / 2.0$ & 1.2 & $0 / 0$ & 0 & $0 / 0$ & 0 \\
\hline & 0.05 & $0 / 0$ & 0 & $0 / 0$ & 0 & $0 / 0$ & 0 \\
\hline DMSO & - & $0 / 0$ & 0 & $0 / 0$ & 0 & $0 / 0$ & 0 \\
\hline$M-C$ & $.5 \mu \mathrm{g} / \mathrm{disk}$ & $4.1 / 13.5$ & 9.4 & $3.0 / 23.5$ & 20.5 & $3.5 / 16.5$ & 12.8 \\
\hline 8-MOP 0. & . $5 \mathrm{mg} / \mathrm{disk}$ & - & - & - & - & $0 / 10.6$ & 10.6 \\
\hline
\end{tabular}

陽性対照物質のマイトマイシン-C $(0.5 \mu \mathrm{g} / \mathrm{disk})$ では, 通常の Rec-assay と Cold incubation を併用したRecassay (Cold-Rec) に执いて, 両株の間に著明な生育阻 止帯の差を示し, DNA 損傷性を認めた。特に Cold-Rec に拈いては, Fig.-1 に示した様に, より感度が増強し,顕
著な結果を示している。また, 光照射併用の Rec-asasy (Photo-Rec) 飞抢ける陽性対照の 8 MOP も，雨株の 間に顥著な生育阻止帯の差を示し， いわゆるPhotodynamic effect が観察された。それに対し，6種の紫 外線吸収剂では, Rec-assay, Cold-Rec, 並びに PhotoRecいずれの試験に和いても，両株の間に生育阻止帯の 差が淘とんど認められず，全て陰性であった。

\section{3-2-2 復帰変異試験結果}

紫外線吸収剂の復帰变異試験結果を Table-7 に示し た。

Table-7. Reversion assay of Sunscreens with or without $\mathrm{S}-9_{\mathrm{mix}}$.

\begin{tabular}{|c|c|c|c|c|c|}
\hline \multirow{3}{*}{ Chrmical } & \multirow{3}{*}{$\begin{array}{c}\text { Concents. } \\
(\mu g / p)\end{array}$} & \multirow{2}{*}{\multicolumn{4}{|c|}{$\begin{array}{l}\text { His }{ }^{+} \text {revertants per plate } \\
\text { TA98 }\end{array}$}} \\
\hline & & & & & \\
\hline & & $-S-9_{\operatorname{mix}}+$ & $+\mathrm{S}-9_{\operatorname{mix}}$ & $-5-9_{\operatorname{mix}}$ & $+\mathrm{S}-9_{\operatorname{mix}}$ \\
\hline \multirow[t]{4}{*}{ Sun - 1} & 1,000 & 43 & 41 & Kill & 185 \\
\hline & 100 & 32 & 40 & 218 & 186 \\
\hline & 10 & 41 & 44 & 218 & 181 \\
\hline & 1 & NT & NT & 210 & NT \\
\hline \multirow[t]{3}{*}{$\operatorname{sun}-2$} & 1,000 & 47 & 42 & 201 & 180 \\
\hline & 100 & 45 & 42 & 188 & 178 \\
\hline & 10 & 39 & 43 & 191 & 179 \\
\hline \multirow[t]{5}{*}{ sun -3} & 1,000 & 17 (Kil1) & 42 & NT & NT \\
\hline & 100 & 33 & 41 & 175 (Kil & 11) 184 \\
\hline & 10 & 43 & 41 & 202 & 188 \\
\hline & 1 & 40 & NT & 200 & 191 \\
\hline & 0.1 & NT & NT & 212 & NT \\
\hline \multirow[t]{3}{*}{$\operatorname{sun}-4$} & 1,000 & 29 & 45 & 205 & 192 \\
\hline & 100 & 35 & 46 & 203 & 191 \\
\hline & 10 & 29 & 46 & 202 & 181 \\
\hline \multirow[t]{3}{*}{ sun -5} & 1,000 & 36 & 44 & Kill & 170 \\
\hline & 100 & 37 & 47 & 206 & 176 \\
\hline & 10 & 31 & 45 & 283 & 177 \\
\hline \multirow[t]{3}{*}{$\operatorname{sun}-6$} & 1,000 & 46 & 44 & 205 & 182 \\
\hline & 100 & 34 & 49 & 213 & 182 \\
\hline & 10 & 35 & 49 & 202 & 189 \\
\hline DMSO & - & 41 & 46 & 205 & 194 \\
\hline $2-\mathrm{NF}$ & 10 & 2286 & - & 2474 & - \\
\hline 2AA & 5 & - & 2304 & - & 2540 \\
\hline
\end{tabular}

陽性対照物質の 2-ニトロフルオレン $(10 \mu \mathbf{g} /$ plate $)$ 並 びに2-アミノアントラセン（ $5 \mu \mathrm{g} /$ plate）では，対照 (DMSO) と比較して, それぞれ著明な復率変異コロニ 一数の増加を, TA 98 並びに TA 100 の両株に対し認め た。しかし，6種の紫外線吸収剂では，本試験の濃度範 囲内で突然変異原性を調べたが，S-9 mix 添加, 無添加 にかかわらず，いずれにおいても，突然変異原性は認め られなかった。

\section{3-3 酸化防止剂の突然变異原性}

\section{3-3-1 DNA 修復試験結果}

8 種の酸化防止㶡について，DNA 修復試験の検討結 果を Table-8 に示した。

陽性対照物質として，Rec-assay 並びに Cold-Rec 
Table-8. Rec-assay of Antioxidants.

\begin{tabular}{|c|c|c|c|c|c|c|c|}
\hline Chemical & $\begin{array}{l}\text { Concents. } \\
\text { (mg/aisk) }\end{array}$ & $\begin{array}{r}\text { Rec } \\
\text { H17/M45 }\end{array}$ & inhibit. & $\begin{array}{l}\text { Cold } \\
\text { Hl7/M45 }\end{array}$ & $\begin{array}{l}\text { a-Rec } \\
\text { inhibit. }\end{array}$ & $\begin{array}{l}\text { Photo } \\
\text { H17/M45 }\end{array}$ & $\begin{array}{l}\text {-Rec } \\
\text { inhibi. }\end{array}$ \\
\hline \multirow[t]{3}{*}{ Anti - 1} & 5.0 & $4.8 / 6.2$ & 1.4 & $4.5 / 4.6$ & 0.1 & $5.6 / 5.6$ & 0 \\
\hline & 0.5 & $0 / 1.1$ & 1.1 & $0 / 0$ & 0 & $0 / 0$ & 0 \\
\hline & 0.05 & $0 / 0$ & 0 & $0 / 0$ & 0 & $0 / 0$ & 0 \\
\hline \multirow[t]{3}{*}{ Anti - 2} & 5.0 & $9.9 / 10.5$ & $5 \quad 0.6$ & $8.7 / 9.3$ & 0.6 & $9.5 / 10.9$ & 0 \\
\hline & 0.5 & $6.2 / 6.8$ & 0.6 & $3.8 / 4.8$ & 1.0 & $5.1 / 5.5$ & 0,4 \\
\hline & 0.05 & $0 / 0$ & 0 & $0 / 0$ & 0 & $0 / 0$ & 0 \\
\hline \multirow[t]{3}{*}{ Anti - 3} & 5.0 & $5.0 / 6.5$ & 1.5 & $7.3 / 8.2$ & 0.9 & $4.9 / 5.4$ & 0.5 \\
\hline & 0.5 & $0 / 0$ & 0 & $0 / 0$ & 0 & $0 / 0$ & 0 \\
\hline & 0.05 & $0 / 0$ & 0 & $0 / 0$ & 0 & $0 / 0$ & 0 \\
\hline \multirow[t]{3}{*}{ Anti - 4} & 5.0 & $3.0 / 4.7$ & 2.7 & $1.1 / 1.1$ & 0 & $0.3 / 0.3$ & 0 \\
\hline & 0.5 & $3.5 / 3.9$ & 0,4 & $1.2 / 1.3$ & 0.1 & $0.5 / 0.5$ & 0 \\
\hline & 0.05 & $2.9 / 3.8$ & 0.9 & $0 / 0.3$ & 0.3 & $0 / 0$ & 0 \\
\hline \multirow[t]{3}{*}{ Anti - 5} & 5.0 & $6.9 / 8.3$ & 1.9 & $9.9 / 10.5$ & 50.6 & $6.5 / 6.6$ & 0.1 \\
\hline & 0.5 & $6.0 / 7.3$ & 1.3 & $6.0 / 6.8$ & 0.8 & $2.9 / 3.0$ & 0.1 \\
\hline & 0.05 & $1.2 / 2.4$ & 1.2 & $0 / 0$ & 0 & $0 / 0$ & 0 \\
\hline \multirow[t]{3}{*}{ Anti - 6} & 5.0 & $7.8 / 9.0$ & 1.2 & $5.8 / 6.6$ & 0.8 & $4.5 / 4.5$ & 0 \\
\hline & 0.5 & $6.7 / 9.3$ & 2.6 & $5.5 / 6.5$ & 1.0 & $2.9 / 3.1$ & 0.2 \\
\hline & 0.05 & $3.4 / 4.6$ & 1.2 & $1.0 / 2.2$ & 1.2 & $0 / 0$ & 0 \\
\hline \multirow[t]{3}{*}{ Anti - 7} & 5.0 & $0 \%$ & 0 & $0 / 0$ & 0 & $0 / 0$ & 0 \\
\hline & 0.5 & $0 / 0$ & 0 & $0 / 0$ & 0 & $0 / 0$ & 0 \\
\hline & 0.05 & $0 / 0$ & 0 & $0 / 0$ & 0 & $0 / 0$ & 0 \\
\hline \multirow[t]{3}{*}{ Anti - 8} & 5.0 & $0 / 1.5$ & 1.5 & $0 / 0$ & 0 & $0 / 0$ & 0 \\
\hline & 0.5 & $0 / 2.2$ & 2.2 & $0 / 0$ & 0 & $0 / 0$ & 0 \\
\hline & 0.05 & $0 / 0$ & 0 & $0 / 0$ & 0 & $0 / 0$ & 0 \\
\hline DMSO & - & $0 / 0$ & 0 & $0 / 0$ & 0 & $0 / 0$ & 0 \\
\hline$M-C$ & $.5 \mu \mathrm{g} / \mathrm{disk}$ & $4.3 / 15.0$ & 10.7 & $2.3 / 17.9$ & 15.6 & - & - \\
\hline 8-MOP $\quad 0$ & $.5 \mathrm{mg} / \mathrm{disk}$ & $2.0 / 4.9$ & 2.9 & - & - & $0 / 8.6$ & 8.6 \\
\hline
\end{tabular}

* inhibit. : Difference of Growth Inhibition zone.

は, マイトマイシンーCを使用し, Photo-Rec には，8MOP を使用した。それぞれの陽性対照では，いずれも H 17 と M 45 の両株の間に顕著な生育阻止带の差を認め た。それに対し，8種の酸化防止剂については， Recassay, Cold-Rec 並びに Photo-Rec いずれの試験に抒 いても, 両株の間に生育阻止帯の差をほとんど認めず, 全て㓌性であった。

\section{3-3-2 復帰変異試験結果}

酸化防止剂についての復帰変異試験結果は Table-9 に示した。

陽性対照物質の2-ニトロフルオレン並びに代謝活性化 の必要な2-アミノアントラセンでは, いずれも対照に比 較し, それぞれ著明な復帰変異コロニ一数の増加を, TA98 並びに TA100 の両株に対して認めた。一方, 8 種の酸化防止剂では, 本試験の濃度範囲内で突然変異原 性を検討したが， S-9 mix 添加, 無添加にかかわらず, いずれに和いても突然变異原性は陰性であった。

\section{3-4 ホルモンの突然変異原性}

\section{3-4-1 DNA 修復試験結果}

7 種のホルモンについての検討結果を Table-10 に示 した。

陽性対照物質のマイトマイシンーC では両秼の間に顕 著な生育阻止帯の差を示した。それに対し，癌原物質を 含む 7 種のホルモンについては，両株の間に生育阻止帯
Table-9. Reversion assay of Antioxidants with or without $\mathrm{S}-9_{\mathrm{mix}}$.

\begin{tabular}{|c|c|c|c|c|c|}
\hline \multirow{3}{*}{ Chemical } & \multirow{3}{*}{$\begin{array}{c}\text { Concents. } \\
(\mu / g / \mathrm{P})\end{array}$} & \multicolumn{4}{|c|}{$\mathrm{His}^{+}$revertants per plate } \\
\hline & & \multicolumn{2}{|c|}{ TA98 } & \multicolumn{2}{|c|}{ TA100 } \\
\hline & & $-s-9 m i x$ & $+\mathrm{S}^{-9} \operatorname{mix}$ & $-S-9_{\operatorname{mix}}$ & ${ }^{+S-9}$ mix \\
\hline \multirow{3}{*}{ Anti - 1} & 1,000 & 29 & 27 & 194 & 218 \\
\hline & 100 & 30 & 23 & 194 & 225 \\
\hline & 10 & 26 & 20 & 196 & 235 \\
\hline \multirow[t]{3}{*}{ Anti - 2} & 100 & 32 & .32 & 187 & 224 \\
\hline & 10 & 39 & 27 & 200 & 227 \\
\hline & $I$ & 31 & 22 & 193 & 221 \\
\hline \multirow[t]{3}{*}{ Anti - 3} & 100 & 31 & 23 & 202 & 218 \\
\hline & 10 & 28 & 22 & 190 & 220 \\
\hline & 1 & 32 & 18 & 212 & 205 \\
\hline \multirow[t]{3}{*}{ Anti -4} & 1,000 & 34 & 35 & kill & kill \\
\hline & 100 & 40 & 26 & 203 & 218 \\
\hline & 10 & 36 & 35 & 207 & 228 \\
\hline \multirow{3}{*}{ Anti - 5} & 100 & 28 & 21 & 196 & 218 \\
\hline & 10 & 35 & 27 & 207 & 228 \\
\hline & I & 33 & 26 & 198 & 226 \\
\hline \multirow[t]{4}{*}{ Anti - 6} & 100 & 30 & 27 & $k i 11$ & 210 \\
\hline & 10 & 39 & 29 & 208 & 226 \\
\hline & 1 & 32 & 28 & 199 & 218 \\
\hline & 0.1 & NT & $\mathrm{NT}$ & 193 & $\mathrm{ATT}$ \\
\hline \multirow[t]{3}{*}{ Anti - 7} & 1,000 & 28 & 24 . & 192 & 227 \\
\hline & 100 & 30 & 27 & 192 & 227 \\
\hline & 10 & 36 & 25 & 203 & 223 \\
\hline \multirow[t]{3}{*}{ Anti -8} & 1,000 & 22 & 31 & 194 & 219 \\
\hline & 100 & 34 & 31 & 189 & 264 \\
\hline & 10 & 34 & 26 & 199 & 223 \\
\hline DMSO & - & 34 & 27 & 197 & 220 \\
\hline $2-\mathrm{NF}$ & 10 & 3,290 & - & 3,492 & - \\
\hline $2 \mathrm{AA}$ & 20 & - & 2,764 & - & 3,394 \\
\hline
\end{tabular}

NT : not tested

Table-10. Rec-assay of Hormones.

\begin{tabular}{|c|c|c|c|c|}
\hline \multirow{2}{*}{ Chemical } & \multirow{2}{*}{$\begin{array}{l}\text { Concents. } \\
\text { (mg/disk) }\end{array}$} & \multicolumn{2}{|c|}{ B.Subutilis. } & \multirow{2}{*}{$\begin{array}{l}\text { Difference } \\
\text { of } \\
\text { Inhibition }\end{array}$} \\
\hline & & $\mathrm{H} 17\left(\operatorname{Rec}^{+}\right)$ & $\mathrm{M} 45\left(\mathrm{Rec}^{-}\right)$ & \\
\hline \multirow{3}{*}{ Hоrm - 1} & 50 & 0 & 0 & 0 \\
\hline & 0.5 & 1.5 & 1.5 & 0 \\
\hline & 0.05 & 0.9 & 1.2 & 0.3 \\
\hline \multirow[t]{3}{*}{ Horm - 2} & 5.0 & 0 & 0 & 0 \\
\hline & 0.5 & 0 & 0 & 0 \\
\hline & 0.05 & 0 & 0 & 0 \\
\hline \multirow[t]{3}{*}{ Horm - 3} & 5.0 & 0 & 0 & 0 \\
\hline & 0.5 & 0 & 0 & 0 \\
\hline & 0.05 & 0 & 1.5 & 1.5 \\
\hline \multirow{3}{*}{ Horm -4} & 5.0 & 0 & 0 & 0 \\
\hline & 0.5 & 0 & 0 & 0 \\
\hline & 0.05 & 0 & 0 & 0 \\
\hline \multirow{3}{*}{ Hогт -5} & 5.0 & 0 & 0 & 0. \\
\hline & 0.5 & 0 & 0 & 0 \\
\hline & 0.05 & 0.9 & 0.9 & 0 \\
\hline \multirow[t]{3}{*}{ Horma -6} & 5.0 & 0 & 0 & 0 \\
\hline & 0.5 & 0.5 & 1.0 & 0.5 \\
\hline & 0.05 & 0 & 0 & 0 \\
\hline \multirow[t]{3}{*}{ Hогm -7} & 5.0 & 1.8 & 1.9 & 0.1 \\
\hline & 0.5 & 0.9 & 0.9 & 0 \\
\hline & 0.05 & 0 & 0 & 0 \\
\hline DMSO & - & 0 & 0 & 0 \\
\hline$M-C$ & $0.5 / \mu \mathrm{g} / \mathrm{d}$ isk & 3.5 & 12.5 & 9.0 \\
\hline
\end{tabular}

の差をほとんど認めず，全て陰性であった。

3-4-2, 復帰変異試験結果

ホルモンの復帰変異試験結果を Table-11 に示した。

陽性対照についての2-ニトロフルオレン並びに代謝活 性化の必要な2-アミノアントラセンでは，いずれも T A 
Table-11. Reversion assay of Hormones with or without S-9mix.

\begin{tabular}{|c|c|c|c|c|c|}
\hline \multirow{3}{*}{ Chemical } & \multirow{3}{*}{$\begin{array}{l}\text { Concents. } \\
(\mu \mathrm{g} / \mathrm{P})\end{array}$} & \multicolumn{4}{|c|}{$\mathrm{His}^{+}$revertants per plate } \\
\hline & & \multicolumn{2}{|c|}{ TA98 } & \multicolumn{2}{|c|}{ TA100 } \\
\hline & & $-s-g_{\operatorname{mix}}$ & $+S-9_{\text {mix }}$ & $-\mathrm{S}-9_{\operatorname{mix}}$ & $+S-9_{\text {mix }}$ \\
\hline \multirow[t]{3}{*}{ Horm -1} & 1,000 & 30 & $43^{*}$ & 205 & 212 \\
\hline & 100 & 29 & 32 & 205 & 212 \\
\hline & 10 & 27 & 21 & 202 & 192 \\
\hline \multirow{3}{*}{ Horm -2} & 1,000 & 26 & kill & 162 & ki1l \\
\hline & 100 & 27 & 31 & 190 & 208 \\
\hline & 10 & 27 & 31 & 191 & 200 \\
\hline \multirow[t]{3}{*}{ Horm - 3} & 1,000 & 28 & 22 & 214 & 186 \\
\hline & 100 & 31 & 29 & 200 & 192 \\
\hline & 10 & 22 & 29 & 196 & 203 \\
\hline \multirow[t]{3}{*}{ Horm -4} & 1,000 & 30 & 33 & 205 & 210 \\
\hline & 100 & 24 & 26 & 214 & 208 \\
\hline & 10 & 26 & 25 & 204 & 176 \\
\hline \multirow[t]{4}{*}{ Horm -5} & 1,000 & 23 & 26 & kill & kill \\
\hline & 100 & 25 & 24 & 170 & 194 \\
\hline & 10 & 31 & 24 & 168 & 162 \\
\hline & 1 & NT & $\mathrm{NT}$ & 175 & 190 \\
\hline \multirow[t]{3}{*}{ Horm -6} & 1,000 & 30 & 32 & kill & 209 \\
\hline & 100 & 24 & 29 & 213 & 226 \\
\hline & 10 & 31 & 24 & 202 & 204 \\
\hline \multirow[t]{3}{*}{ Horm -7} & 10 & 30 & 39 & 208 & 200 \\
\hline & 1 & 25 & 25 & 162 & 229 \\
\hline & 0.1 & 28 & 23 & 162 & 203 \\
\hline DMSO & - & 28 & 29 & 208 & 215 \\
\hline $2-\mathrm{NE}$ & 2 & 755 & - & 413 & - \\
\hline $2 \mathrm{AA}$ & 5 & - & 1,773 & - & 2,872 \\
\hline
\end{tabular}

* : The number of revertants represents to be slightly more than the controls.

NT : not tested.

98並びに TA100 の両株において, 顕著な復州変異コロ ニ一数の増加が見られた。一方, 7 種のホルモン中, エ ストラジオール (Horm-1) のみに, 高濃度で, 対照 (DMSO) より, わずかに高い復帰変異コロニ一数の増 加が, サルモネラ TA 98株(+S-9 mix)で, 見られた。 しかしその突然変異原性を認めるには到らなかった。 その他の癌原性物質を含む6種のホルモンについてもま た，全て陰性であった。

\section{3-5 界面活性肪の突然変異原性}

\section{3-5-1 DNA 修復試験結果}

界面活性剂については, アニオン系, カチオン系, ノ ニオン系界面活性剂, 両性界面活性剂等, 代表的な各種 界面活性剤 17 種について, DNA 修復試験を検討した。 その結果を Table-12 に示した。

陽性対照物質のマイトマイシンーC では両株の間に顕 著な生育阻止帯の差を認めたのに対し，17種全ての界面 活性剤には, いずれも両株の間に, 生育阻止帯の差をほ とんぞ認めず, 陰性であった。

\section{3-5-2 復帰変異試験結果}

17 種の界面活性剂の復帰変異試験結果を Table-13 亿 示した。

陽性対照物質の2-ニトロフルオレンならびに代謝活性 化の必要な2-アミノアントラセンでは, いずれも対照
Table-12. Rec-assay of Surfactants.

\begin{tabular}{|c|c|c|c|c|c|}
\hline \multirow{2}{*}{ Chemical } & \multirow[t]{2}{*}{ Solvent } & \multirow{2}{*}{$\begin{array}{l}\text { Concents. } \\
\text { (mg/aisk) }\end{array}$} & \multicolumn{2}{|c|}{ B. Subtilis. } & \multirow{2}{*}{$\begin{array}{l}\text { Difference } \\
\text { of } \\
\text { inhibition }\end{array}$} \\
\hline & & & $\operatorname{R17}\left(\operatorname{Rec}^{+}\right)$ & $M 45\left(\operatorname{Rec}^{-}\right)$ & \\
\hline \multirow[t]{3}{*}{ Surf - 1} & DMSO & 5.0 & 1.0 & 1.7 & 0.7 \\
\hline & & 0.5 & 0.9 & 1.1 & 0.2 \\
\hline & & 0.05 & 0 & 0.3 & 0.3 \\
\hline \multirow[t]{3}{*}{ Surf -2} & DMSO & 5.0 & 3.3 & 4.1 & 0.8 \\
\hline & & 0.5 & 1.0 & 1.4 & 0.4 \\
\hline & & 0.05 & 0 & 0.5 & 0.5 \\
\hline \multirow[t]{3}{*}{ Surf -3} & $\mathrm{H}_{2} \mathrm{O}$ & 5.0 & 2.6 & 3.1 & 0.5 \\
\hline & & 0.5 & 0 & 2.3 & 2.3 \\
\hline & & 0.05 & 0 & 1.5 & 1.5 \\
\hline \multirow[t]{3}{*}{ Surf -4} & DMSO & 5.0 & 5.4 & 6.3 & 0.9 \\
\hline & & 0.5 & 3.0 & 3.0 & 0 \\
\hline & & 0.05 & 0.3 & 0.5 & 0.2 \\
\hline \multirow[t]{3}{*}{ Surf -5} & DMSO & 5.0 & 0 & 0 & 0 \\
\hline & & 0.5 & 0 & 0 & 0 \\
\hline & & 0.05 & 0 & 0 & 0 \\
\hline \multirow[t]{3}{*}{ Surf -6} & $\mathrm{H}_{2} \mathrm{O}$ & 5.0 & 7.5 & 7.8 & 0.3 \\
\hline & & 0.5 & 4.7 & 4.7 & 0 \\
\hline & & 0.05 & 3.2 & 3.5 & 0.3 \\
\hline \multirow[t]{3}{*}{ Surf -7} & DMSO & 5.0 & 11.6 & 12.1 & 0.5 \\
\hline & & 0.5 & 6.3 & 6.7 & 0.4 \\
\hline & & 0.05 & 3.3 & 3.3 & 0 \\
\hline \multirow[t]{3}{*}{ Surf -8} & DMSO & 5.0 & 13.5 & 13.6 & 0.1 \\
\hline & & 0.5 & 12.2 & 12.6 & 0.4 \\
\hline & & 0.05 & 7.5 & 7.9 & 0.4 \\
\hline \multirow[t]{3}{*}{ Surf - 9} & DMSO & 5.0 & 1.0 & 0.9 & 0.1 \\
\hline & & 0.5 & 0.4 & 0.7 & 0.3 \\
\hline & & 0.05 & 0.5 & 0.5 & 0 \\
\hline \multirow[t]{3}{*}{ Surf -10} & $\mathrm{H}_{2} \mathrm{O}$ & 5.0 & 1.5 & 1.3 & 0.2 \\
\hline & & 0.5 & 2.5 & 2.5 & 0 \\
\hline & & 0.05 & 2.2 & 2.4 & 0.2 \\
\hline \multirow[t]{3}{*}{ Surf -11} & DMSO & 5.0 & 1.9 & 2.0 & 0.1 \\
\hline & & 0.5 & 0 & 0 & 0 \\
\hline & & 0.05 & 0 & 0 & 0 \\
\hline \multirow[t]{3}{*}{ Surf -12} & DMSO & 5.0 & 0 & 0 & 0 \\
\hline & & 0.5 & 0 & 0 & 0 \\
\hline & & 0.05 & 0 & 0 & 0 \\
\hline \multirow[t]{3}{*}{ Surf -13} & DMSO & 5.0 & 0 & 0 & 0 \\
\hline & & 0.5 & 0 & 0 & 0 \\
\hline & & 0.05 & 0 & 0.6 & 0.6 \\
\hline Surf -14 & DMSO & 5.0 & 0 & 0 & 0 \\
\hline & & 0.5 & 0 & 0.3 & 0.3 \\
\hline & & 0.05 & 0.3 & 0.3 & 0 \\
\hline Surf -15 & DMSO & 5.0 & 0 & 0 & 0 \\
\hline & & 0.5 & 0 & 0 & 0 \\
\hline & & 0.05 & 0 & 0 & 0 \\
\hline Surf -16 & DMSO & 5.0 & 8.0 & 8.1 & 0.1 \\
\hline & & 0.5 & 3.1 & 3.1 & 0 \\
\hline & & 0.05 & 1.4 & 1.5 & 0.1 \\
\hline Surf -17 & $\mathrm{H}_{2} \mathrm{O}$ & 5.0 & 3.4 & 3.4 & 0 \\
\hline & & 0.5 & 2.5 & 2.9 & 0.4 \\
\hline & & 0.05 & 0 & 0 & 0 \\
\hline DMSO & & - & 0 & 0 & 0 \\
\hline $\mathrm{H}_{2} \mathrm{O}$ & & - & 0 & 0 & 0 \\
\hline$M-C$ & & $0.5 \mu \mathrm{g} / \mathrm{disk}$ & 3.6 & 12.7 & 7.6 \\
\hline
\end{tabular}

(DMSO) に比較し, TA 98 と TA 100 の両株の系で, 顕著な復帰変異コロニ一数の増加があった。しかるに, TA98株系での代謝活性化（+S-9 mix）による復帰変異 試験の結果, アニオン系界面活性剂のポリオキシェチレ ン（3）ラウリルェーテルサルフェート(Surf 1), トリ エタノールアミンラウリルェーテルサルフェート (Surf-2), ソジウムラウリルサルフェート（Surf-4） の 3 種とノニオン系界面活性剤のポリオキシェチレン (15) セチルェーテル (Surf-13), ポリオキシェチレン (16) ラノリンアルュール (Surf-14) の 2 種について は, 高濃度領域で対照 (DMSO) より, そのコロニー数 
Table-13. Reversion assay of Surfactants with or without S-9mix.

\begin{tabular}{|c|c|c|c|c|c|c|}
\hline \multirow{3}{*}{ ChemicaI } & \multirow{3}{*}{ Solvent } & \multirow{3}{*}{$\begin{array}{c}\text { Concents. } \\
(\mu g / p)\end{array}$} & \multicolumn{4}{|c|}{$\mathrm{His}^{+}$, revertants per plate } \\
\hline & & & \multicolumn{2}{|c|}{ TA98 } & \multicolumn{2}{|c|}{ TA100 } \\
\hline & & & $-s-9_{\operatorname{mix}}$ & $+5-9_{\operatorname{mix}}$ & $-s-9_{\operatorname{mix}}$ & $+S-9_{\operatorname{mix}}$ \\
\hline \multirow[t]{3}{*}{ Surf -1} & DMSO & 1,000 & 28 & $43^{*}$ & 199 & 171 \\
\hline & & 100 & 20 & $41^{*}$ & 218 & 168 \\
\hline & & 10 & 23 & 21 & 215 & 171 \\
\hline \multirow[t]{4}{*}{ surf - 2} & DMSO & 1,000 & Kill & $46^{*}$ & 228 & NT \\
\hline & & 100 & 24 & $45^{\star}$ & 220 & 139 \\
\hline & & 10 & 20 & 29 & 169 & 178 \\
\hline & & 1 & 20 & 30 & NT & 169 \\
\hline \multirow[t]{4}{*}{ Surf -4} & DMSO & 1,000 & Kill & $42^{*}$ & 216 & Kill \\
\hline & & 100 & 27 & $48^{*}$ & 251 & 169 \\
\hline & & 10 & 24 & 38 & 210 & 166 \\
\hline & & 1 & 25 & 31 & NT & 165 \\
\hline \multirow{3}{*}{ Surf -7} & DMSO & 10 & 26 & 28 & 215 & 148 \\
\hline & & 1 & 26 & 32 & 200 & 178 \\
\hline & & 0.1 & 23 & 35 & 216 & 179 \\
\hline \multirow[t]{3}{*}{ Surf -8} & DMSO & 5 & 23 & 26 & 208 & $96 \mathrm{Kill}$ \\
\hline & & 1 & 26 & 27 & 214 & 130 \\
\hline & & 0.1 & 29 & 29 & 214 & 145 \\
\hline \multirow[t]{3}{*}{ Surf - 9} & DMSO & 1,000 & 30 & 25 & 229 & 177 \\
\hline & & 100 & 33 & 28 & 210 & 177 \\
\hline & & 10 & 28 & 27 & 208 & 175 \\
\hline \multirow[t]{3}{*}{ Surf -11} & DMSO & 1,000 & 31 & 31 & 205 & 163 \\
\hline & & 100 & 29 & 33 & 203 & 166 \\
\hline & & 10 & 32 & 26 & 214 & 172 \\
\hline DMSO & & - & 28 & 29 & 213 & 178 \\
\hline $2-\mathrm{NF}$ & & 2 & 755 & - & 413 & - \\
\hline $2 \mathrm{AA}$ & & 5 & - & 1,773 & - & 960 \\
\hline \multirow[t]{3}{*}{ Surf -3} & $\mathrm{H}_{2} \mathrm{O}$ & 1,000 & 31 & 38 & 199 & 197 \\
\hline & & 100 & 32 & 33 & 204 & 212 \\
\hline & & 10 & 27 & 33 & 207 & 214 \\
\hline Surf -5 & DMSO & 1,000 & 35 & 38 & 201 & 213 \\
\hline & & 100 & 29 & 33 & 210 & 198 \\
\hline & & 10 & 33 & 36 & 191 & 198 \\
\hline Surf -6 & $\mathrm{H}_{2} \mathrm{O}$ & 10 & 32 & 33 & 207 & 207 \\
\hline & & 1 & 24 & 29 & 206 & 204 \\
\hline & & 0.1 & 30 & 24 & 205 & 191 \\
\hline Surf -10 & $\mathrm{H}_{2} \mathrm{O}$ & 100 & 17Kill & 34 & 196 & 198 \\
\hline & & 10 & 26 & 27 & 195 & 202 \\
\hline & & 1 & 26 & 29 & 196 & 201 \\
\hline Surf -12 & DMSO & 1,000 & 27 & 36 & 203 & 204 \\
\hline & & 100 & 28 & 38 & 205 & 208 \\
\hline & & 10 & 26 & 34 & 201 & 190 \\
\hline Surf -13 & DMSO & 1,000 & 25 & $49^{*}$ & 196 & 199 \\
\hline & & 100 & 30 & $47^{*}$ & 205 & 199 \\
\hline & & 10 & 19 & $42^{*}$ & 200 & 198 \\
\hline Surf -14 & DMSO & 1,000 & $37^{\star}$ & $48^{*}$ & 200 & 205 \\
\hline & & 100 & 29 & 37 & 206 & 210 \\
\hline & & 10 & 20 & 32 & 205 & 210 \\
\hline Surf -15 & DMSO & 2,000 & 32 & 31 & 208 & 193 \\
\hline & & 100 & 29 & 31 & 208 & 199 \\
\hline & & 10 & 29 & 36 & 199 & 219 \\
\hline Surf -16 & DMSO & 100 & 27 & 34 & 193 & 186 \\
\hline & & 10 & 28 & 33 & 207 & 209 \\
\hline & & 1 & 26 & 33 & 203 & 207 \\
\hline Surf -17 & $\mathrm{H}_{2} \mathrm{O}$ & 1,000 & Kill & Kill & Kill & 204 \\
\hline & & 100 & 31 & 28 & 190 & 200 \\
\hline & & 10 & 32 & 24 & 207 & 207 \\
\hline & & 1 & 27 & 27 & 207 & 207 \\
\hline DMSO & & - & 29 & 33 & 202 & 204 \\
\hline $\mathrm{H}_{2} \mathrm{O}$ & & - & 27 & 32 & 199 & 202 \\
\hline $2-\mathrm{NF}$ & & 2 & 657 & - & 275 & - \\
\hline $2 \mathrm{AA}$ & & 5 & - & 1,680 & - & 1,383 \\
\hline
\end{tabular}

* : The number of revertants represents to be slightly more than the controls.

NT : not tested.

は少ないが，わずかに高い復帰変異コロニ一数を示し た。ポリオキシェチレン(16)ラノリンアルコールでは, また代謝活性化なし(-S-9 mix) で, TA 98 株に, 対照 よりわずかに高值の復帰変異コロニー数が見られた。し
かしこれらの結果は, 突然変異原性を認める程には到ら なかった。

その他のアニオン系 2 種, カチオン系 3 種, ノニオン 系 5 種の活性剤に加え, 両性界面活性剂の 2 種では, 全 て陰性であった。

TA 100 株の場合, S-9 mix 添加, 無添加にかかわら ず，17種全ての界面活性剂に，いずれも復帰変異コロニ 一数の増加が症とんぞ認められず, 陰性であった。

\section{4. 考察}

厚生省がん研究班は17)，防腐剤について，突然変異原 性を検討して和りメチル，エチル，ブチルーp-オキシ安 息香酸エステルでの Rec-assay 並びにサルモネラ菌に よる復帰変異試験結果は，いずれも陰性であると報告し ている。ところが，プロピルーp-オキシ安息香酸エステ ルでは, Rec-assay に和いて陽性を示し, 復帰変異試験 結果は陰性であった。しかし，我々の検討では 4 種のpオキシ安息香酸エステル（Pre-1,2, 3,4）については, Rec-assay, 復帰変異試験のいずれにおいても, 陰性の 結果を得た。但し，我々が取り上げた 9 種の防腐剂中， Irg-DP 300 のみに，実用濃度の約 100 倍に相当する高 濃度に扣いて弱いRec 陽性を認めた。他の全ての防腐剤 では, Rec-assay 並びに復帰変異試験に打いて陰性で あった。

紫外線吸収剂は, 太陽光線遮断剂として使用されるこ とから, 通常の Rec-assay, Cold-Rec 就よび復帰変異 試験に加え光照射条件下の Rec-assay (Photo-Rec) に より，その突然変異原性を検討した。その結果取り上げ た紫外線吸収剂 6 種は，いずれも陰性であった。

今回, Photo-Rec の陽性対照物質として用いた 8MOP は植物界に広く分布しているフロクマリンの一種 として知られ，ヒト皮膚上で紫外線暴露により炎症を起 こして, 色素沈着を起こす光毒物質として知られてい る。また，8-MOP については，M. J.Ashwood-Smith 等により， ${ }^{18}$ 近紫外 $(320 \sim 380 \mathrm{~nm})$ 照射下， E. Coli WP2 $\left(\right.$ Try $\left.^{-}\right)$株に, 突然変異原性を誘発することが報告 されている。我々は，8-MOP の DNA 損傷性について 溃光灯照射下, 検討した。その結果, Fig.-1 に示した 様に H 17 Ｍ 45 の両株の間に顕著な生育阻止帯の差を 認めた。そして同様な現象が O-201でも見い出された。 この様な Photo-dynamic effect は, 賀田等によって ${ }^{19)}$, フロキシンBにも認められている。しかし，若干光毒性 の報告 ${ }^{20,21)}$ もあるエスカロール506については, 光照射 
下に执いても DNA 損傷性は確認できなかった。

酸化防止剂については，厚生省がん研究班によってい くつか検討されており ${ }^{17)}$, 石館が総説として詳しく報告 している ${ }^{14)}$ 。 BHT, BHA, 没食子酸プロピル, $d l-\alpha-卜$ ロフェロール，L-アスコルビル酸は，復帰変異試験で は，全て陰性であるが，Rec-assay においては，BHA， BHT 和よび没食子酸プロピルに陽性が認められたと報 告している。我々の結果では, いずれの試験法でも, 全 て陰性であった。賀田等は，代謝活性化を併用したり， 液体プレート法等の検討より, これらの 3 種の酸化防止 剤に陽性を認めたとしているが，本実験では，これらの 方法は未検討である。

合成女性ホルモンとして知られているジェチルスチル ベステロールは癌原物質として知られて和り，この突然 変異原性については，厚生省がん研究班に和いても検討 されている17)。すなわち, Rec-assay で陽性を示し, 復 帰変異試験に和いては陰性と報告している。H.R. Glatt 等も ${ }^{22)}$, 種々の代謝系を併用した復帰変異試験により, ジェチルスチルベステロールについて検討しているが， いずれも突然変異原性は陰性であると報告している。我 々の試験でも, Rec-assay, 復帰変異試験いずれの方法 でも陰性であった。

また，M. F. E1. Etreby は28)，エストラジオール， エチニルエストラジオールが, 高濃度で, マウス, ラッ 卜に腫瘍発生を促進すると報告している。しかし R. Lang 等は23), その突然変異原性は陰性であったと報告 している。

エチニルエストラジオールについては, 我々の結果で も陰性であった。また，エストラジオールについては， 医薬部外品規制值 $(0.002 \%)^{24)}$ の約 50 倍に相当する高濃 度において, 対照 (DMSO) に比較し, やや復帰変異コ ロニー数の増加が認められる。しかしコロニ一数の増加 杼よび Dose-Response の関係は，突然変異原性を認め るには必ずしも充分でないことから，㓌性と判断した。 その他の 4 種のホルモンについては, 全て陰性であっ た。

界面活性剂については, 厚生省がん研焭班や17), 井上 等15,16)の報告がある。Polysorbate 60 は弱い助発癌物 質といわれ25,26)，マウス皮膚に塗布することにより，若 干ではあるが，腫瘍発生がみられるといわれている27\%。 この Polysorbate 60 の突然変異原性について, 厚生省 がん研究班は, 復㷌 変異試験では陰性であるが, Recassay では陽性であると報告している
等は, 15,16), 同様の Rec-assay, 復帰変異試験のいずれ に持いても陰性であったと報告している。我々も同様に 粧原基グレードの Polysorbate 60 で Rec-assay 拉よ び復州変異試験を検討したところ, いずれの方法でも陰 性であり, 井上等の結果と全く同じであった。さらに, Polysorbate 80 についても, ラットに皮下連続投与によ り線維肉腫を認めるという報告があるが， ${ }^{29}$ 我々の突然 変異原性試験の結果は，陰性であった。

一方, 他の界面活性剤については, サルフェート系の アニオン界面活性剤 3 種とセチルェーテル及びラノリン アルコール系ノニオン界面活性剂の 2 種に执いて，1 $10 \mathrm{mg} / \mathrm{ml}$ で, サルモネラ TA98 に対照(DMSO)よりわず かに高い復帰変異コロニー数の増加がみられた。しか し, エストラジオールと同様に, 突然变異原性を認める には到っていない。その他の界面活性剤アニオン系 2 種, カチオン系 3 種, ノニオン系 3 種並びに両性界面活 性剂 2 種もまた, いずれの試験に打いても, 突然変異原 性は陰性であった。

\section{5. 総 括}

5-1 防腐剤 9 種の内, Irg-DP 300 に, 弱い DNA 損 傷性を認めたものの復帰変異試験では陰性であった。そ の他の防腐剤の突然変異原性は, 全て陰性であった。

\section{5-2}

紫外線吸収剂 6 種の突然変異原性は, 全て陰性であっ た。

\section{5-3}

酸化防止剤 8 種の突然変異原性は, 全て陰性でめっ た。

\section{5-4}

ホルモン 7 種の内, エストラジオールのみサルモネラ TA 98 (+S-9 mix) に, 高濃度でわずかに高い復帰変異 コロニー数の増加を認めたが, 突然変異原性を認めるに 到らなかった。一方, 一部癌原物質を含む他のホルモン の突然変異原性は, 全て除性であった。

\section{5-5}

界面活性刘の場合, サルフェート系のアニオン界面活 性剂 3 種とセチルエーテル及びラノリンアルコール系ノ ニオン界面活性剤 2 種が， $1 \sim 10 \mathrm{mg} / \mathrm{m} \ell$ サルモネラ TA 98 に，対照 (DMSO) よりわずかに高い復帰変異誘 発を示したが突然変異原性を認めるに到っていない。

その他の界面活性剂12種の突然変異原性は全て陰性で あった。 


\section{引用文献}

1) S. Kondo and H. Ichikawa, Japan, J. Genetics, 48, 295 300 (1973)

2) T. Kada, Japan, J. Genetics, 48, 301 305 (1973)

3) A. Tonomura and T. Sasaki, Japan, J. Genetics, 48, 291 294 (1973)

4) Y. Ikeda, Report to Food Sanitary Committee of the ministry of Health and Welfare, (1974)

5) T. Sugimura, T. Kawachi, M. Nagao, Y. Seino, T. Okamoto, K. Shudo, T. Kosuge. K. Isugi, K. Wakabayashi, Y. Iitake and A. Itai, Proc, Japan, Acad, 53, 58 61 (1977)

6) S. Takayama, Y. Katoh, M. Tanaka, M. Nagao, K. Wakabayashi and T. Sugimura, Proc, Japan, Acad, 53, Ser, B, 126 129 (1 977)

7）松倉則夫, 河内卓, 内田英二, 森野一英, 大垣比 吕子, 杉村隆, 高山昭三, 第39回日本癌学会総会 記事 (東京) 5, November, 32 (1980)

8）賀田恒夫編，“遺伝毒性突然変異実験法”日本衛 生技術研究会

9) B. N. Ames, J. MacCCan, and E. Yamasaki, Mutation, Res, 31, 347 364 (1975)

10) B.N. Ames, H. O. Kammen and E. Yamasaki, Proc, Nat, Acad, Sci, USA, $72[6], 2423 \sim$ 2427, June (1975)

11) C. E. Searle, D. G. Harden, S. Venitt and O. H. B. Gyde, Nature, 255, June, 5, 306 307 (1975)

12) T. Kada, K. Tutikawa andY. Sadaie, Mutation Res, 16. 165 174 (1972)

13）松島泰次郎 et al, 日本環境変異原研究会第 5 回研究発表会要旨 (東京) 16, October (1976)

14）石館基, フレグランスジャーナル。No.12，66〜 70 (1980)
15) K. Inoue, T. Sunagawa and S. Takayama, 10 th, I. F. S.C.C. Congress, Australia Vol.1, $139 \sim 178$ (1978)

16）井上邦夫, 砂隆, 高山昭三, J. Soc. Cosmet, Chem, Japan, Vol.13, No.2,50 60 (1979)

17）厚生省がん研究報告書 (下) (Annual Report of the Cancer Research Ministry of Health and Welfare）河内班, (1973 1978)

18) M. G. Ashwood-Smith, G. A. Poulton, M. Barker and Mildenberger, Nature, 285, 5, June $407 \sim 409$ (1980)

19) K. Yoshikawa. H. Kurata, S. Iwahara and T. Kada, Mutation, Res, 56, 359 362 (1978)

20) E.A. Emmett, B. R. Taphorn and J. R. Kominsky, Arch Dermatol, 113, June, 770 775 (1977)

21) K. H. Kaidbey \& A. M. Kligman, Arch Dermator 114, April, 547 549 (1978)

22) H. R. Glatt, M. Metzler and F. Oesch, Mutation, Res, 67, No.2, 113 121 (1976)

23) R. Lang and U. Redmann, Mutation, Res, 67, 361 365 (1979)

24）化粧品原料基準第 1 版追補注解，薬事日報社， p. 718

25) H, Setälä, Acta, Acta, Pathol, Microbial, Scand, Supp, 115, 1 (1956)

26) K. Setälä, H. Setälä and P.P.Holsti, Science, 120, 1075 (1954)

27) G. Dellaporta, P. Shubik, K. Dammert and' B. Terracini, J. Nat1, Cancer Inst, 25, 607 (1960)

28) M. F. El, Etreby, A short review, in W. I. P. Mainwarning, E. Genazzani, F. Dicarlo (Eds), Pharmacological Modulation of steroid Action, Raven, New York, in Press.

29) P. Grasso et al, Food \& Cosmet, Toxicol 9, 463 (1971)

（昭和56年 9 月 18 日受理） 